\title{
Modeling of a Photovoltaic Array in MATLAB Simulink and Maximum Power Point Tracking Using Neural Network
}

Khanam $\mathrm{J}^{*}$ and Foo SY

Department of Electrical and Computer Engineering, FAMU-FSU College of Engineering, Tallahassee, Florida

\begin{abstract}
In this paper, we present our work on Maximum Power Point Tracking (MPPT) using neural network. The MATLAB/ Simulink is used to establish a model of photovoltaic array. The Simulink model is tested with different temperature and irradiation and resultant I-V and P-V characteristics proved the validation of Simulink model of PV array. We collected a set of data from the Simulink model of PV array after simulated under a range of irradiation and temperature. The data collected from the system is used to train the neural network. When we tested the neural network with different irradiance and temperature, we see that the neural network can accurately predict the maximum power point of a photovoltaic array. In this paper, the backpropagation training algorithm is used to train the neural network. Comparisons of MPPT with P \& O algorithm and without MPPT tracker are also shown in this paper. It is demonstrated that the neural network based MPPT tracking require less time and provide more accurate results than the P\&O algorithm based MPPT.
\end{abstract}

Keywords: MPPT; MPP; Maximum power $\left(\mathrm{P}_{\max } / \mathrm{P}_{\mathrm{mp}}\right)$; Voltage at maximum power point $\left(\mathrm{V}_{\max } / \mathrm{V}_{\operatorname{mp}}\right)$; Neural network; Perturb and observe; Irradiance $\left(\mathrm{I}_{\mathrm{rr}}\right)$ and Photovoltaic $(\mathrm{PV})$

\section{Introduction}

Maximum Power Point Tracking (MPPT) is very useful tool in PV application. Solar radiation and temperature are the main factor for which the electric power supplied by a photovoltaic system varies. The voltage at which $\mathrm{PV}$ module can produce maximum power is called 'maximum power point' (or peak power voltage) [1-3]. The main principle of MPPT is responsible for extracting the maximum possible power from the photovoltaic and feed it to the load via dc to dc converter which steps up/steps down the voltage to required magnitude. Various MPPT techniques have been used in past but Perturb \& Observe ( $\mathrm{P} \& \mathrm{O})$ algorithm is most widely accepted [4-6]. P\&O algorithm has also been shown to provide wrong tracking with rapidly varying irradiance [7-10]. In this paper we are implemented neural network based MPPT method. Artificial Neural Network (ANN) is an artificial network that can able to mimic the human biological neural networks behavior. ANN widely used in modeling complex relationships between inputs and outputs in nonlinear systems. ANN can also be defined as parallel distributed information processing structure. The ANN consists of inputs, and at least one hidden layer and one output layer. These layers have processing elements which are called neurons interconnected together. To calculate error contribution of each neuron after a batch of data processing a method called 'backpropagation' is used. Backpropagation is commonly used by the gradient descent optimization algorithm to adjust the weight of neurons by calculating the gradient of the loss function. This technique is also called backpropagation error. This is because the error is calculated at the output and circulated back through the network layers [11].

\section{Mathematical Solar Array Modeling}

In this paper at first, we modelled a $60 \mathrm{~W} \mathrm{PV}$ array. The basic building block of PV arrays is the solar cell, which is basically a p-n semiconductor junction, shown in Figure 1.

The following equations define the model of a PV panel:

$$
\mathrm{I}_{\mathrm{pv}}=\frac{\mathrm{G}}{\mathrm{G}_{\mathrm{r}}}\left[\left(\mathrm{T}_{\mathrm{c}}-\mathrm{T}_{\mathrm{ref}}\right) \mathrm{K}_{\mathrm{i}}+\mathrm{I}_{\mathrm{sc}}\right]
$$

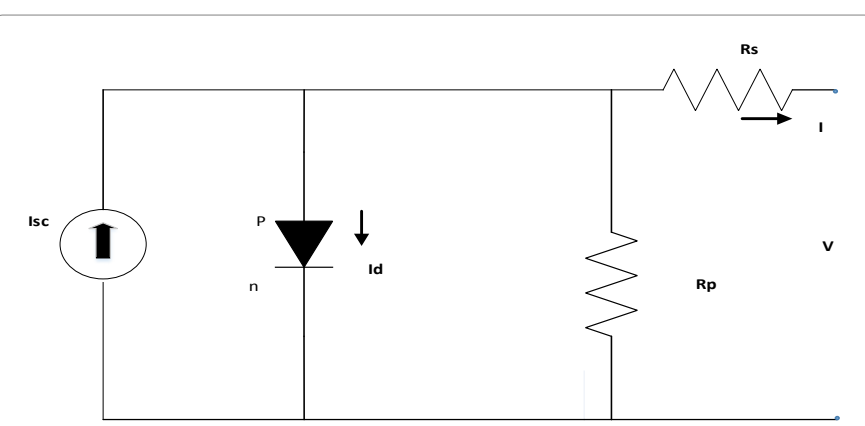

Figure 1: Equivalent model for solar cell.

$$
\begin{aligned}
& I_{d}=\left(e^{\frac{q\left(V+I^{*} R_{s}\right)}{K^{*} T_{c}^{*} N_{s}^{*}{ }^{* A}}}-1\right) \times I_{s} \times N_{p} \\
& I_{r s}=I_{s c} /\left(e^{\frac{q^{*} V_{o c}}{\mathrm{~N}_{s}^{*}{ }^{*} A^{*} T_{c}}}-1\right) \\
& I_{s}=I_{r s}\left(\frac{T_{c}}{T_{r e f}}\right)^{3} \times e^{\frac{q^{*} E_{g}}{A * K}}\left(\frac{1}{T_{c}}-\frac{1}{T_{r e f}}\right) \\
& I_{s h}=\frac{V+I^{*} R_{s}}{R_{p}}
\end{aligned}
$$

*Corresponding author: Khanam J, Department of Electrical and Computer Engineering, FAMU-FSU College of Engineering, Tallahassee, Florida 32310, USA, Tel: +1 850-410-6161; E-mail: jk16c@fsu.edu

Received June 22, 2018; Accepted July 09, 2018; Published July 16, 2018

Citation: Khanam J, Foo SY (2018) Modeling of a Photovoltaic Array in MATLAB Simulink and Maximum Power Point Tracking Using Neural Network. J Electr Electron Syst 7: 263. doi: 10.4172/2332-0796.1000263

Copyright: $\odot 2018$ Khanam J, et al. This is an open-access article distributed under the terms of the Creative Commons Attribution License, which permits unrestricted use, distribution, and reproduction in any medium, provided the original author and source are credited. 


$$
I=I_{p v}-I_{d}-I_{\text {sh }}
$$

Where, 'Ipv' is the light generated current (it is directly proportional to the solar irradiation), 'Is' is the saturation or leakage current of the diode. The reverse saturation current of a cell is 'Irs', 'I' is output current from the PV panel. 'Id' is diode current or dark current. ' $\mathrm{A}$ ' is the ideality constant of a silicon diode. 'Tc' and 'Tref' are the working temperature of cell and reference temperature, respectively in ${ }^{\circ} \mathrm{K}$. 'Ns' is number of cells in series for a PV module. $\mathrm{Np}$ is number of parallel module. Eg is the band gap energy of semiconductor. Voc is the open circuit voltage and Isc the short circuit current. Rs and Rsh are series and parallel resistances of solar cell, respectively [12]. The typical PV characteristics of a solar cell shown in Figure 2. In the figure we can observe that at voltage ' $\mathrm{V}$ ' ' the power is at the maximum. This is the maximum power point of PV characteristics that we need to track using MPPT algorithm [13].

\section{Modeling and Simulation of 60W PV array}

The solarex MSX60 PV array is chosen for our modeling and simulation. The typical electrical characteristics of MSX60 modules, each consisting of 36 polycrystalline silicon solar cells, are given in Table 1. $\mathrm{P}-\mathrm{V}$ characteristics curves obtained from the simulation for MSX 60 modules at $\mathrm{T}_{\mathrm{c}}=25^{\circ} \mathrm{C}\left(298^{\circ} \mathrm{K}\right)$ and $\mathrm{G}_{\mathrm{r}}=1000 \mathrm{~W} / \mathrm{m}^{2}, \mathrm{~A}=1.3, \mathrm{~N}_{\mathrm{s}}=36, \mathrm{~Np}=$ $1 ; \mathrm{T}_{\text {ref }}=298^{\circ} \mathrm{K}\left(25^{\circ} \mathrm{C}\right) ; \mathrm{E}_{\mathrm{g}}=1.12 \mathrm{eV} ; \mathrm{R}_{\mathrm{sh}}^{\mathrm{r}}=1000 \Omega ; \mathrm{R}_{\mathrm{s}}=0.1 \Omega[14]^{\mathrm{s}}$.

For the modeling of PV array, we used MATLAB Simulink. The simulation model in Figures 3-7 are based on equations 1 to 6 .

Simulink model of an MSX $60 \mathrm{PV}$ array subsystem is shown in Figure 8. P-V characteristics of the PV array with variation of irradiance and temperature shown in Figure 9 and Figure 10. The effect of series and shunt resistance on I-V characteristics is shown in Figure 11 and Figure 12 respectively.

The output obtained from the model exactly matches with the data provided by the P-V characteristics of MSX 60. In Figure 9 we observed with irradiance increased, power increased. In Figure 10 we observed

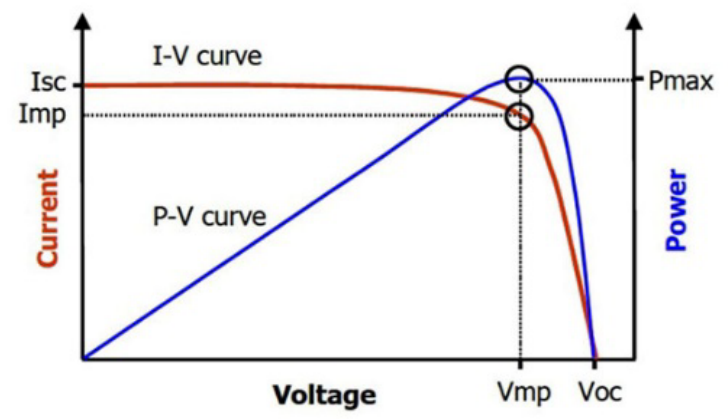

Figure 2: Typical I-V and PV characteristics of a PV module.

\begin{tabular}{|c|c|}
\hline Description & MSX 60 \\
\hline Maximum power & $60 \mathrm{~W}$ \\
\hline Voltage at $\mathrm{P}_{\max }\left(\mathrm{V}_{\max }\right)$ & $17.1 \mathrm{~V}$ \\
\hline Current at $\mathrm{P}_{\max }\left(\mathrm{I}_{\mathrm{m}}\right)$ & $3.5 \mathrm{~A}$ \\
\hline Guaranteed minimum $\mathrm{P}_{\mathrm{m}}$ & $58 \mathrm{~W}$ \\
\hline Short Circuit current $\left(\mathrm{I}_{\mathrm{sc}}\right)$ & $3.8 \mathrm{~A}$ \\
\hline Open circuit voltage $\left(\mathrm{V}_{\mathrm{oc}}\right)$ & $21.1 \mathrm{~V}$ \\
\hline Temperature coefficient $\mathrm{K}_{\mathrm{i}}$ & $(0.065 \pm 0.15) \mathrm{A} /{ }^{\circ} \mathrm{C}$ \\
\hline
\end{tabular}

Table 1: Electrical Characteristics of MSX $60 \mathrm{PV}$ module.

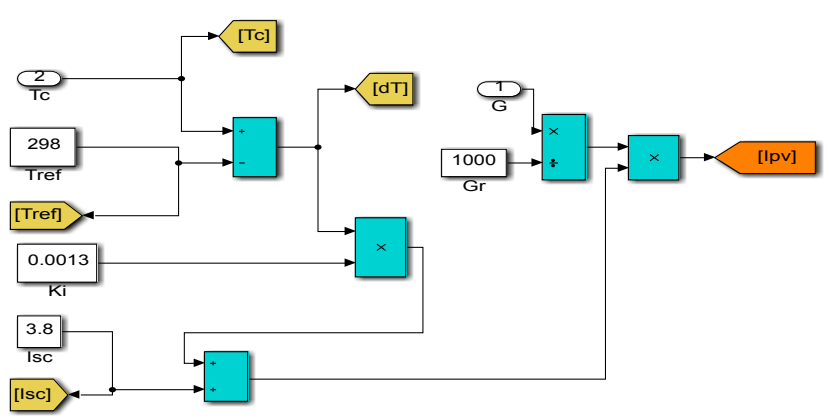

Figure 3: Simulation model for calculation of Ipv.

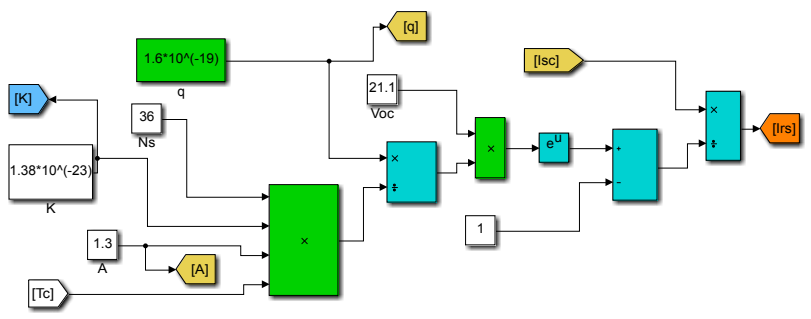

Figure 4: Simulation model for calculation of Irs.

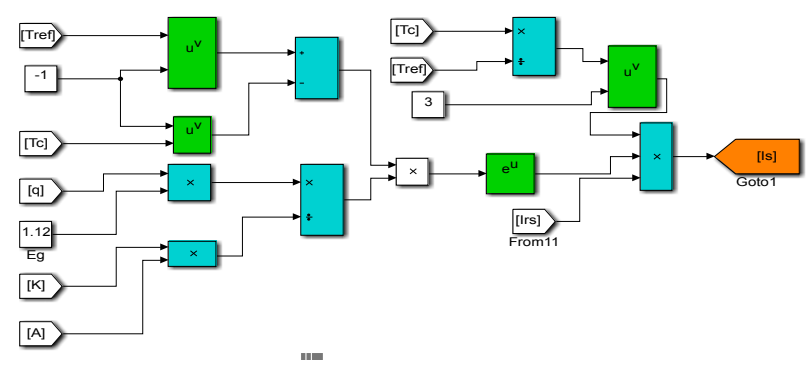

Figure 5: Simulation model for calculation of Is.

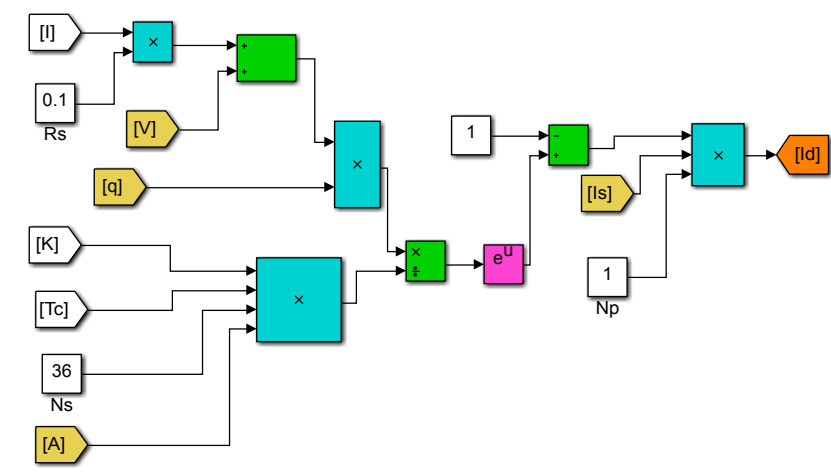

Figure 6: Simulation model for calculation of Id.

with temperature increased, power decreased. From Figures 11 and 12 with series resistance increased, current decreased, whereas if shunt resistance increases, current increases. Hence our Simulink model is exactly able to determine the characteristics of PV array. Hence the Simulink model is accurate. 


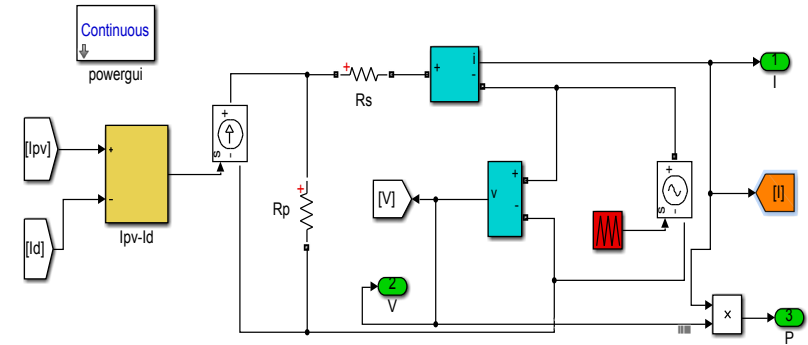

Figure 7: Simulation model for calculation of $\mathrm{I}$.

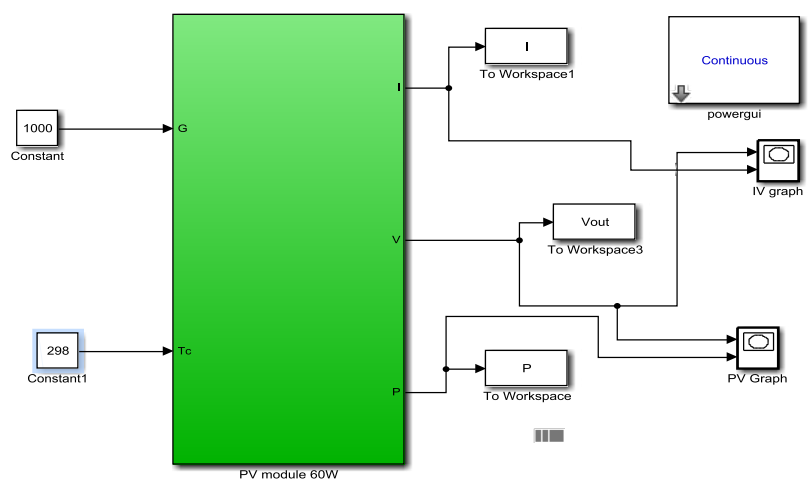

Figure 8: Simulink model of MSX 60 PV array subsystem without load.

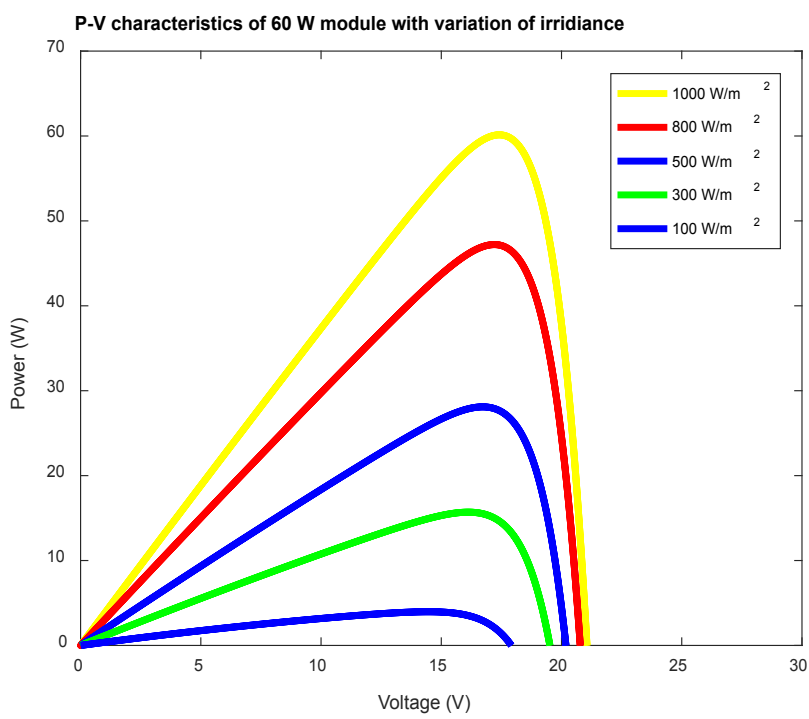

Figure 9: P-V characteristics of $60 \mathrm{~W}$ PV array with variation of irradiance.

\section{Classical P\&O Algorithm}

Here the P \& O algorithm MPPT technique is used in $60 \mathrm{~W}$ modelled PV array to find maximum power point. The block diagram of general MPPT Photo Voltaic system is shown in the following Figure 13 [15].

To track the MPP of PV module, P\&O MPPT algorithms have been used. The P \& O algorithm shown in Figure 14. P\&O operates by periodically perturbing (incrementing or decrementing) the PV array

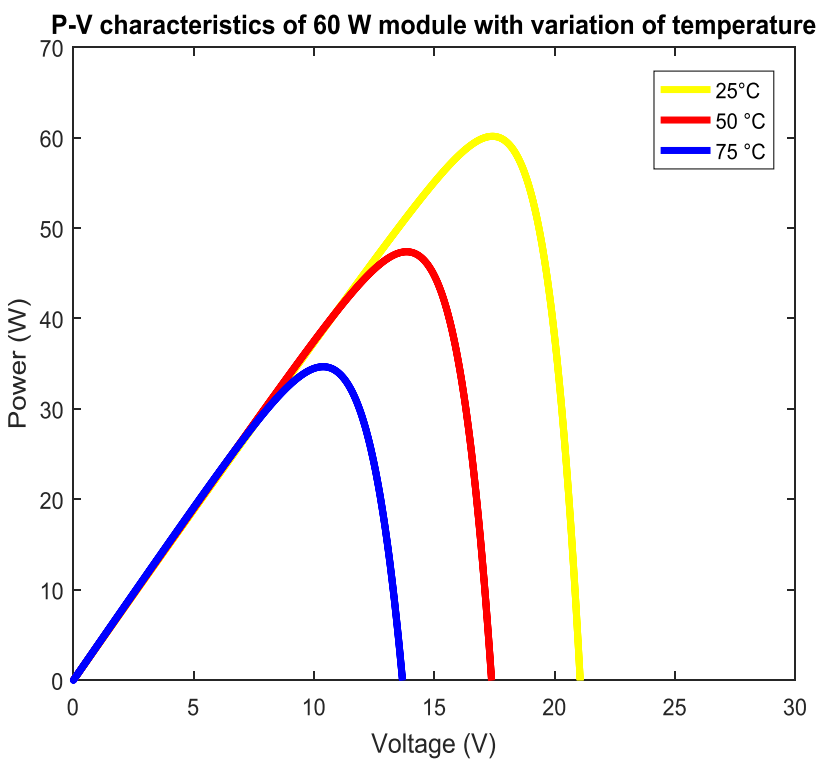

Figure 10: P-V characteristics of $60 \mathrm{~W} P V$ array with variation of temperature.

$\mathrm{I}-\mathrm{V}$ characteristics of $60 \mathrm{~W}$ module with variation of series resistance

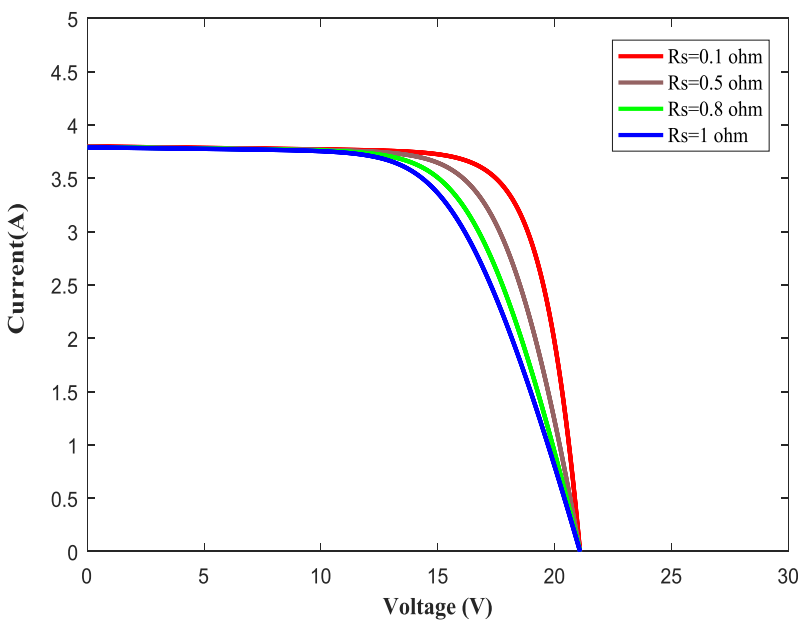

Figure 11: I-V graph for effect of variation of series resistance in $60 \mathrm{~W}$ module.

terminal voltage or current and comparing the corresponding output power of $\mathrm{PV}$ array $\mathrm{P}(\mathrm{K})$ with that at the previous perturbation $\mathrm{P}(\mathrm{K}-1)$. In reference voltage perturbation, the $\mathrm{PV}$ array output voltage reference is used as the control parameter in conjunction with a controller (PI/ PID controller) to adjust the duty ratio of the MPPT converter. From Figure 15 we can see that, if the perturbation in terminal voltage leads to an increase in power $(\mathrm{dP} / \mathrm{dV}>0)$, the perturbation should be kept in the same direction otherwise the perturbation is moved to the opposite direction. The perturbation cycle is repeated until the maximum power is reached at the $\mathrm{dP} / \mathrm{dV}=0$ [16-21]. The perturbation size is kept very small intentionally. It helps to keep the power variation small. PV array with $\mathrm{P} \& \mathrm{O}$ algorithm based MPPT tracking is shown in Figure 16.

The comparison between with and without MPP tracking is shown in Figure 17, where we can see that, without MPPT tracker the maximum power point is $37.31 \mathrm{~W}$. While, when we used P \& O based MPPT tracking the maximum power point become $53.94 \mathrm{~W}$. The 


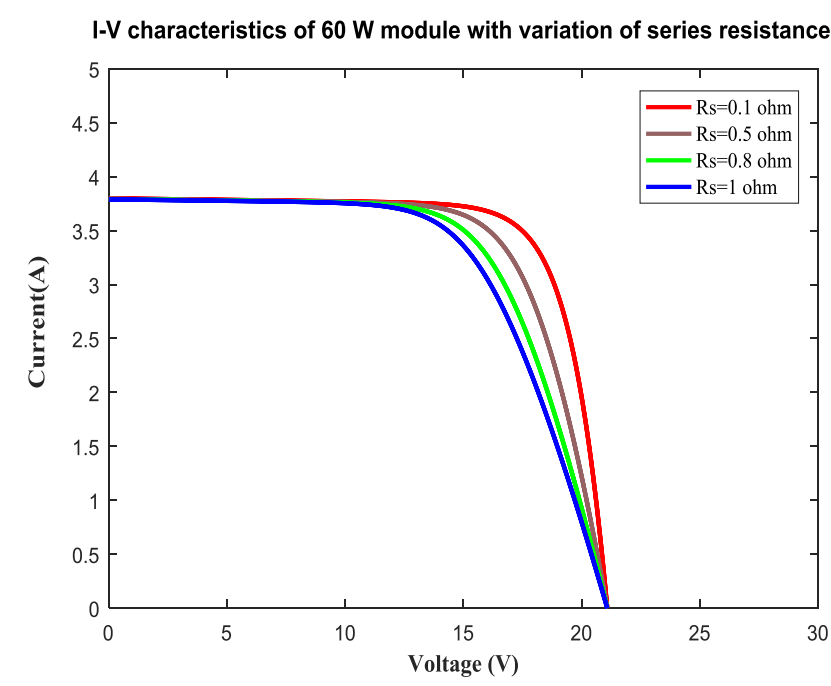

Figure 12: I-V graph for effect of variation of shunt resistance in $60 \mathrm{~W}$ module.

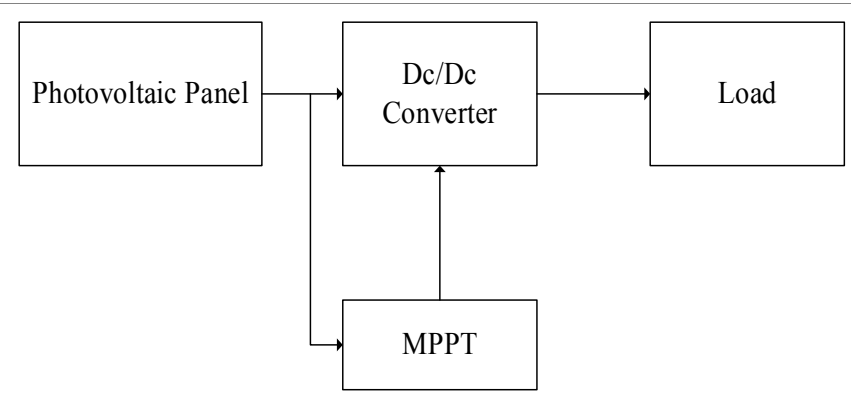

Figure 13: Block diagram of MPPT Photo Voltaic system.

simulation results of the solar PV with MPPT P\&O algorithm is shown in Figure 18, From Figure 18 we can see that at $14.33 \mathrm{~V}$ we are getting maximum power $53.94 \mathrm{~W}$. We also have observed, that it takes only 0.07213 minutes to track the maximum power point.

\section{Neural Network Based MPPT Tracking}

Here neural network is used to track MPP of our implemented $60 \mathrm{~W}$ PV array. In our work, the Levenberg-Marquardt algorithm is implemented using MATLAB to train the neural network. The Levenberg-Marquardt method is a very fast and accurate technique for solving nonlinear least squares problems. Since the variations of temperature and irradiance effect are highly nonlinear in producing the output power and voltage, we decided to use the Levenberg-Marquardt algorithm to train the neural network. The following steps describe how we implement the neural network based MPPT for a PV array.

\section{Selecting network structure}

The input information is connected to the hidden layers through weighted interconnections where the output data is calculated. The number of hidden layers and the number of neurons in each layer controls the performance of the network. Neural network is a trial and error design method. The ANN developed in this paper with two inputs solar irradiance and temperature, one output layer consists of two neurons $\left(\mathrm{V}_{\max }, \mathrm{P}_{\max }\right)$ and one hidden layer, shown in Figure 19. As the problem is not linearly separable hence it will require a hidden layer with neurons with "tan sigmoid" activation function. Sigmoid function

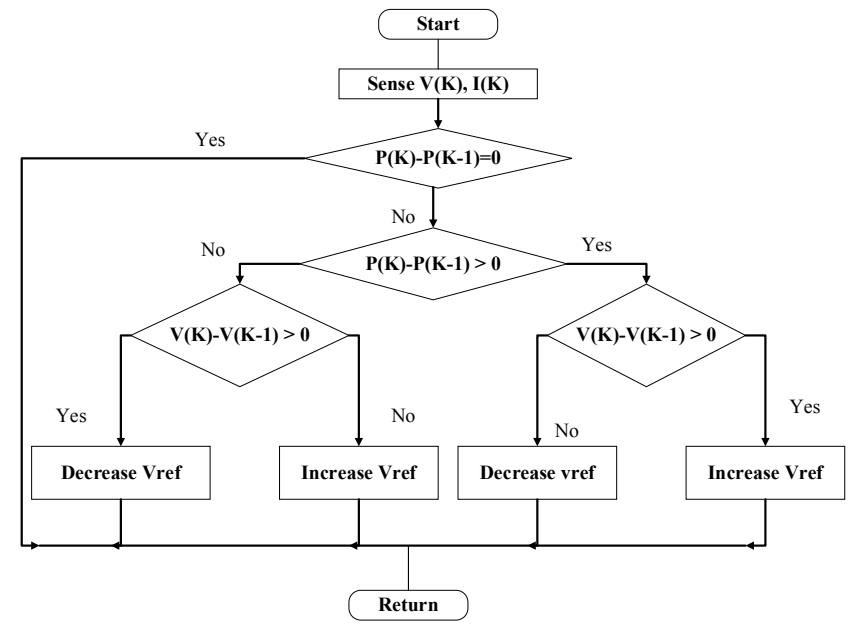

Figure 14: $P$ \& O MPPT algorithm.

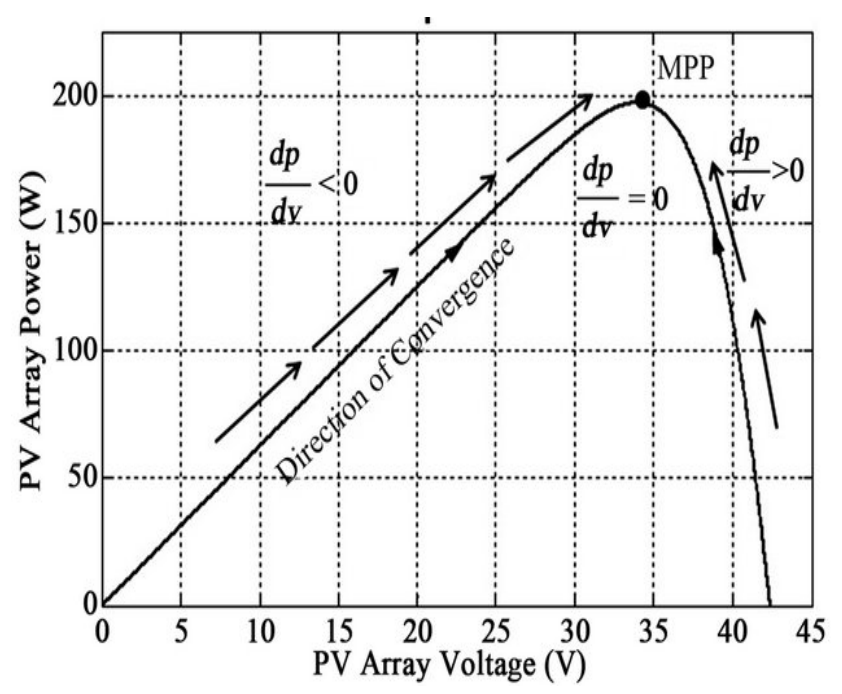

Figure 15: $\mathrm{P}$ and $\mathrm{O}$ based MPPT technique.

is used because it is differentiable. The one output layer has two neurons with "purelinear" activation function which is linear transfer function.

\section{Collecting data}

The Simulink model of PV array is simulated for a range of solar irradiances and temperatures to find corresponding $\mathrm{P}_{\max }$ and $\mathrm{V}_{\text {max }}$ shown in Figure 20. A set of $104 \mathrm{P}_{\max }$ and $\mathrm{V}_{\max }$ data points are derived from the Simulink simulation.

\section{Training the network}

From the set of 104 data points, 94 data points are used as training data. The training points are passed into the designed network to teach it how to perform when different points than the training points are inserted to it.

\section{Testing the network}

After training of the neural network is completed, then 10 of the collected data points are used as test points. The function of test points is to evaluate the performance of the designed ANN after its training is finished. The error is then feedback to the neural network for further 


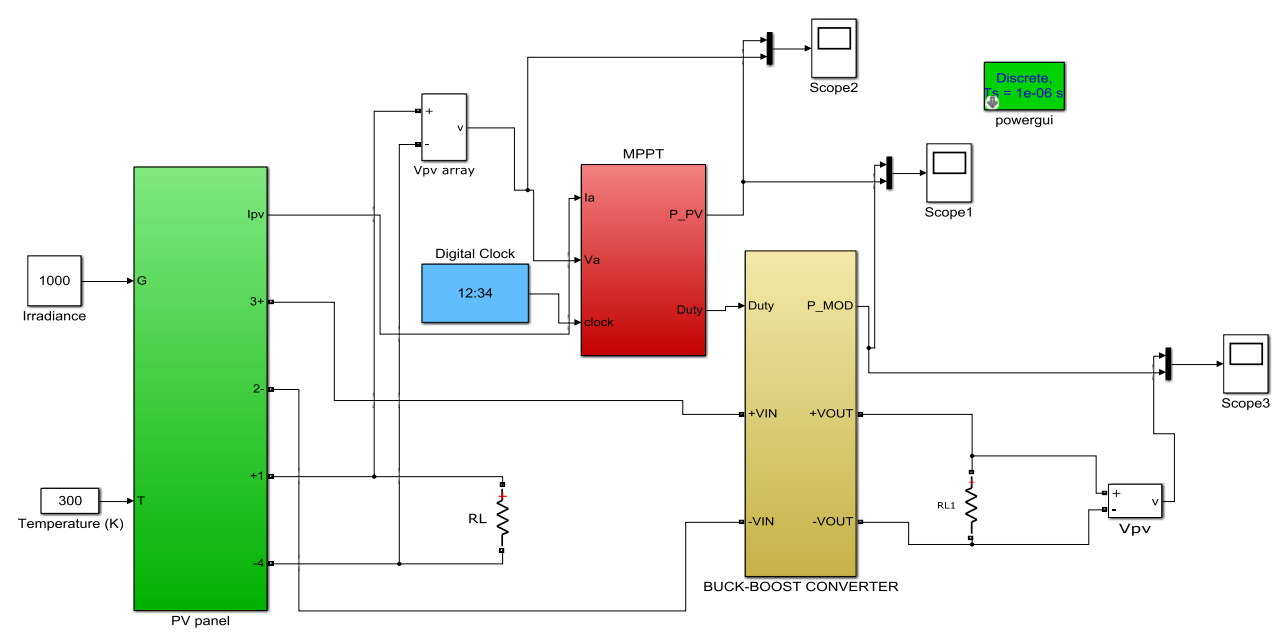

Figure 16: PV array with $P$ \& $O$ algorithm based MPPT tracking

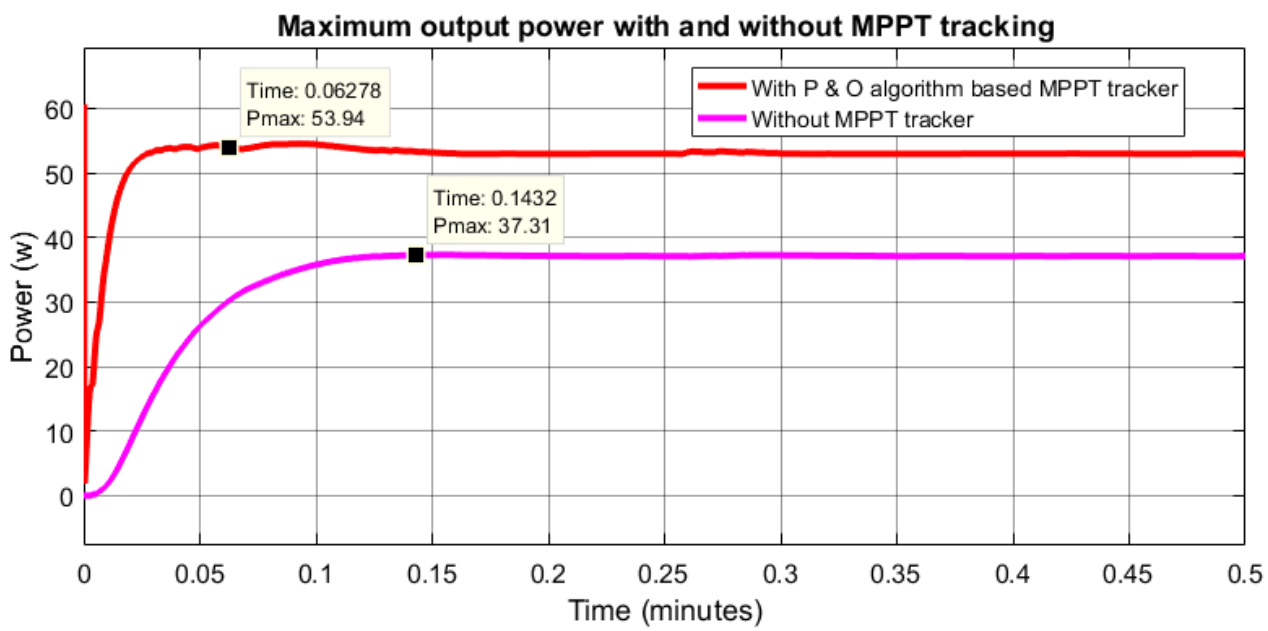

Figure 17: With MPPT \& without MPPT Pmax and Vmax of PV array.

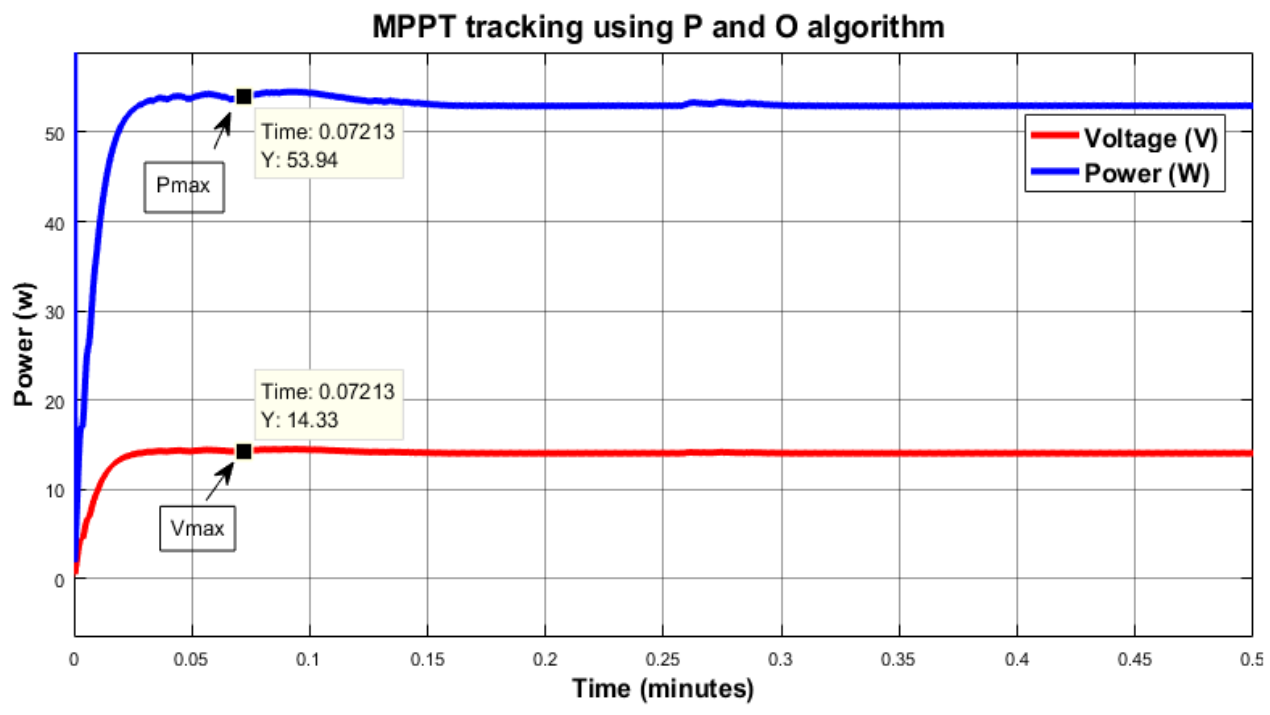

Figure 18: With P \& O MPPT Pmax and Vmax of PV array. 
Citation: Khanam J, Foo SY (2018) Modeling of a Photovoltaic Array in MATLAB Simulink and Maximum Power Point Tracking Using Neural Network. J Electr Electron Syst 7: 263. doi: 10.4172/2332-0796.1000263

Page 6 of 8

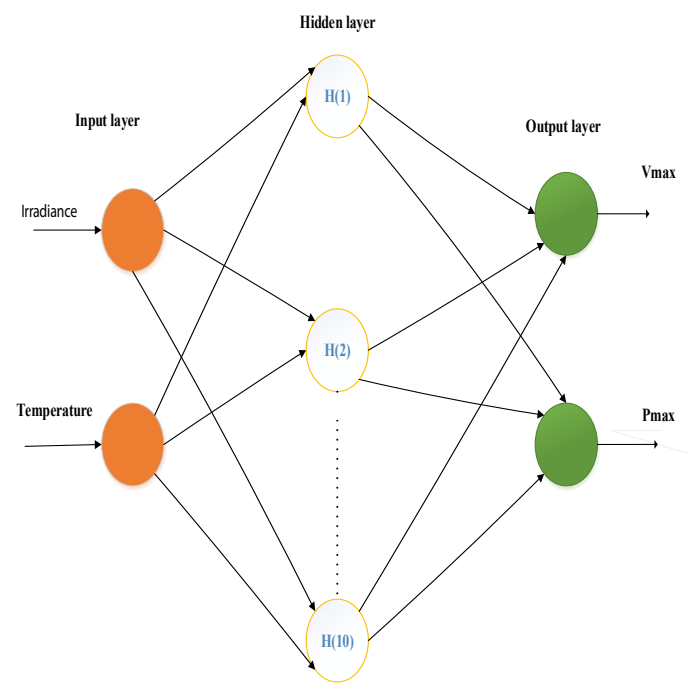

Figure 19: For MPPT proposed ANN structure.

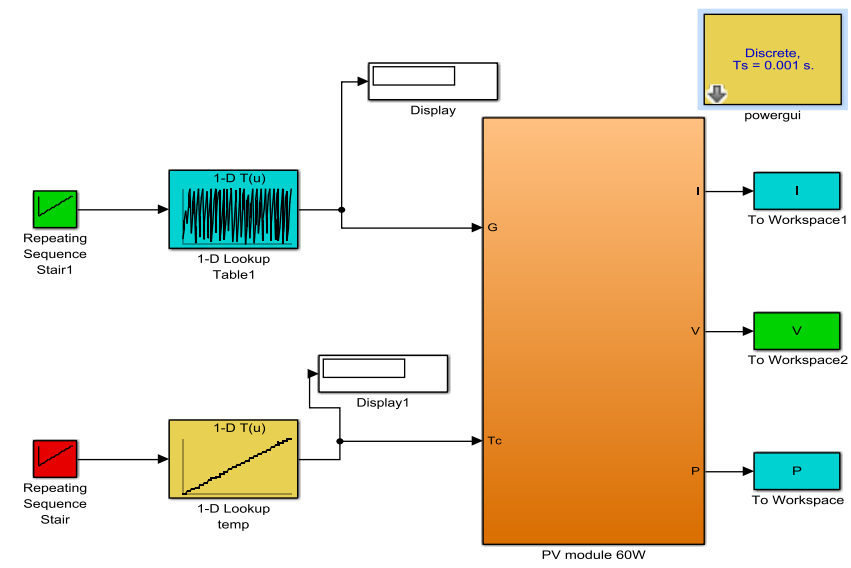

Figure 20: Simulink model of $\mathrm{PV}$ array with resistive load (Battery resistance) for actual Pmax and Vmax data collection.

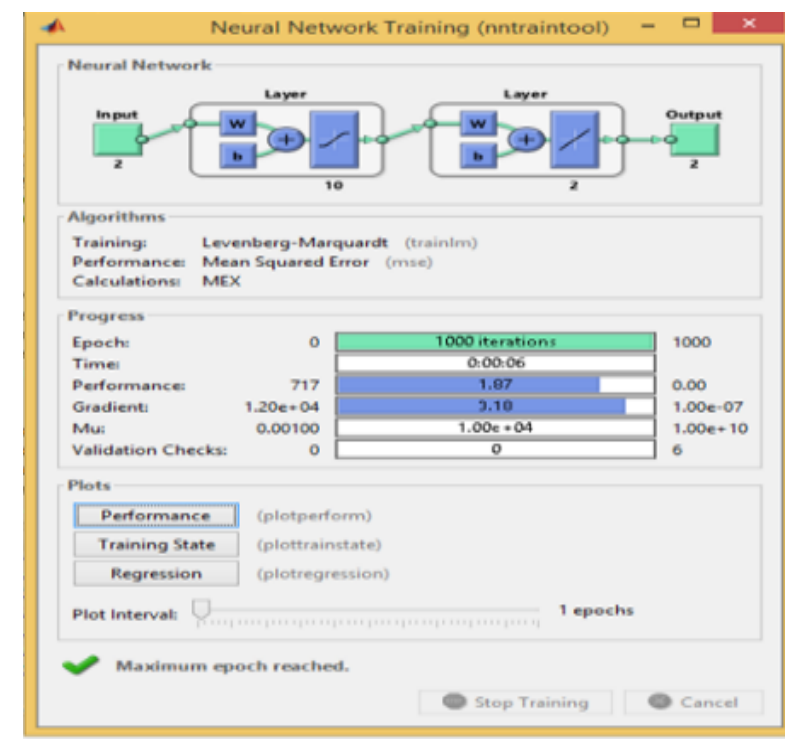

Figure 21: ANN training with MATLAB NNET toolbox.

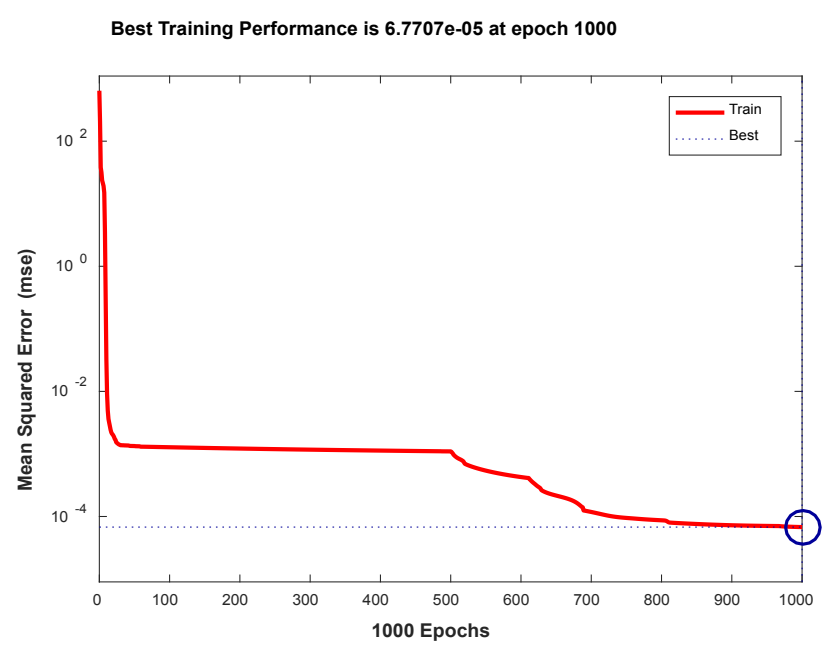

Figure 22: Training performance curve.

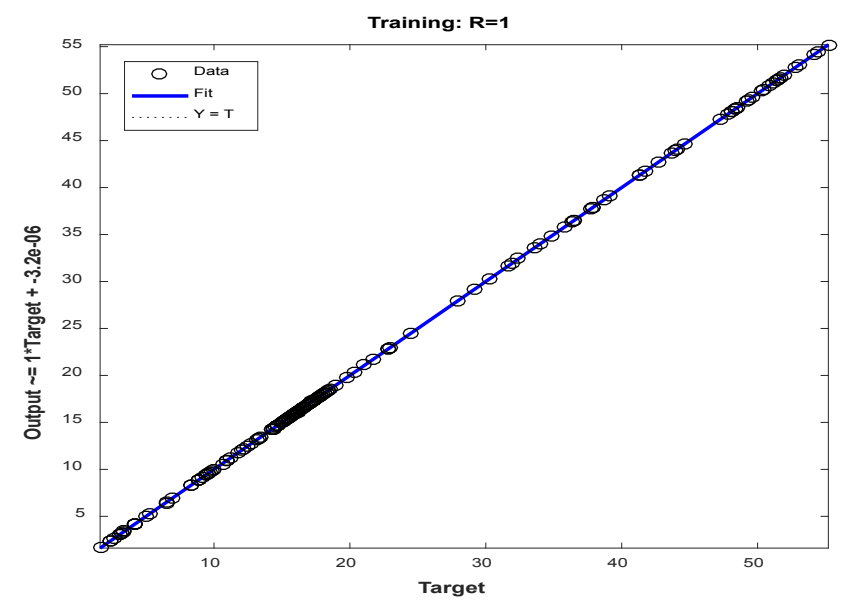

Figure 23: Regression Plot.

\begin{tabular}{|c|c|c|c|c|c|c|}
\hline $\begin{array}{c}\text { Test } \\
\text { Point }\end{array}$ & $\begin{array}{c}\text { Irradiance } \\
\mathbf{W} / \mathbf{m}^{2}\end{array}$ & $\begin{array}{c}\text { Temperature } \\
\text { in }{ }^{\circ} \mathbf{K}\end{array}$ & $\begin{array}{c}\mathbf{V}_{\mathbf{m p}} \\
\mathbf{a c t u a l}\end{array}$ & $\mathbf{V}_{\mathrm{mp}} \mathbf{N N}$ & $\mathbf{P}_{\mathbf{m p}}$ actual & $\mathbf{P}_{\mathbf{m p}} \mathbf{N N}$ \\
\hline 1 & {$[800,291]$} & 291 & 17.724 & 17.8007 & 41.0356 & 41.0449 \\
\hline 2 & {$[1000,300]$} & 300 & 16.88 & 16.8174 & 51.1766 & 51.1813 \\
\hline 2 & {$[500,300]$} & 300 & 15.614 & 15.6228 & 20.405 & 20.4183 \\
\hline 4 & {$[240,310]$} & 310 & 11.816 & 11.8301 & 5.9104 & 5.9089 \\
\hline 5 & {$[600,293]$} & 293 & 16.88 & 16.8582 & 27.52 & 27.3494 \\
\hline 6 & {$[400,302]$} & 302 & 14.77 & 14.7676 & 14.4407 & 14.4022 \\
\hline 7 & {$[700,312]$} & 312 & 14.77 & 14.6336 & 29.7503 & 29.7581 \\
\hline 8 & {$[500,313]$} & 313 & 13.926 & 13.8895 & 18.7714 & 18.8061 \\
\hline 9 & {$[125,299]$} & 299 & 6.752 & 6.9196 & 1.6425 & 1.5521 \\
\hline 10 & {$[440,296]$} & 296 & 16.036 & 15.8739 & 17.2106 & 17.2097 \\
\hline
\end{tabular}

Table 2: For 10 irradiance and temperature data input, the actual and neural network output data $\mathrm{P}_{\mathrm{mp}}$ and $\mathrm{V}_{\mathrm{mp}}$. 


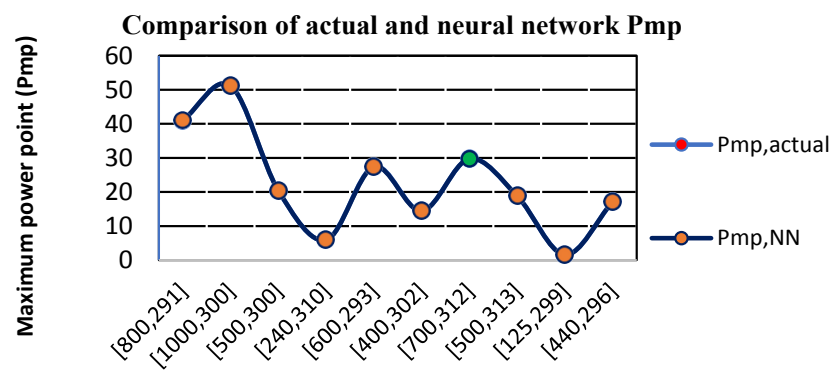

Temperature and irradiance data point $\left[\operatorname{Irr}\left(\mathrm{W} / \mathrm{m}^{2}\right), \mathrm{T}\left({ }^{\circ} \mathrm{K}\right)\right]$

Figure 24: $P_{m p}$ from neural network and actual Simulink model with different testing point.

\section{Comparison of actual and neural network Vmp}

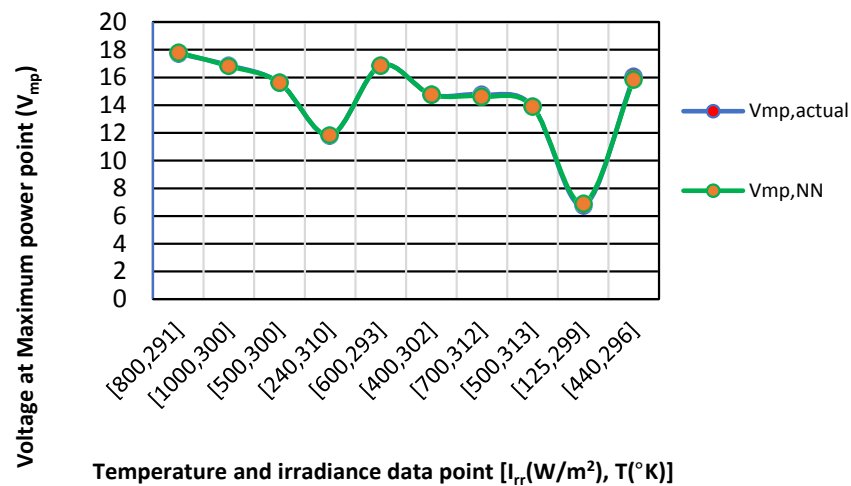

Figure 25: $V_{m p}$ from neural network and actual Simulink model with different testing point.

training. The network is trained using the MATLAB NNET tool box shown in Figure 21.

\section{Results and Discussion for Neural Network MPPT}

The network which was fully trained with the lowest error is capable to be used in the testing process. Performance of ANN to minimize the RMS error is shown in the training performance curve of Figure 22. Network was trained until it achieved a very small MSE typically 0.67707 e-5 which reached after 1000 epochs. From the regression plot in Figure 23, we can observe that the outputs from the neural model closely match the target values.

For 10 new testing input irradiance and temperature data points the neural network has been tested. These data point are $\left[\mathrm{I}_{\mathrm{rr}}\left(\mathrm{W} / \mathrm{m}^{2}\right), \mathrm{T}\left({ }^{\circ} \mathrm{K}\right)\right]$ $=[800,291],[1000,300],[500,300],[240,310],[600,293],[400,302]$, [700,312], [500,313], [125,299] and [440,296] shown in Table 2. In shown in Figure 24 and Figure 25 we can see that, at each time, the neural network provided $\mathrm{P}_{\max }$ and $\mathrm{V}_{\max }$ data points clearly matched with measured data points from the actual Simulink model (Figure 20).

\section{Conclusion}

Extracting the maximum power out of the PV array is a critical step in harvesting renewable energy. The goal of MPPT technique is to extract the maximum power available in the PV array. The Simulink model of MPPT using P\&O algorithm is simulated for a constant irradiation of $1000 \mathrm{~W} / \mathrm{m}^{2}$ and temperature of $27^{\circ} \mathrm{C}\left(300{ }^{\circ} \mathrm{K}\right)$ for which we get $53.94 \mathrm{~W}$ across the load at $14.33 \mathrm{~V}$. It has been shown that simulations of solar PV array without MPPT provided 37.31W of power. This shows that the use of MPPT in PV arrays have improved the efficiency of solar PV system and maximized the output power. When we used a neural network to predict the maximum power point at the same irradiances and temperature, we were able to obtain output power of $51.1813 \mathrm{~W}$ at $16.8174 \mathrm{~V}$. The actual Simulink model of PV array shows maximum power of $51.1766 \mathrm{~W}$ at $16.8800 \mathrm{~V}$. Hence the neural network algorithm can predict more accurate results than the classic P\&O algorithm based MPPT method. Also, the simulations of the neural network require much less $\mathrm{CPU}$ time than the $\mathrm{P} \& \mathrm{O}$ based MPPT methods.

\section{Data Availability}

The research article data used to support the findings of this study are included within the article.

\section{Acknowledgement}

This work is funded in part by Florida A\&M University and Florida State University.

\section{References}

1. Kaundinya DP, Balachandra P, Ravindranath NH (2009) Grid-connected versus standalone energy systems for decentralized power: A review of literature. Renew Sust Energ Rev 13: 2041-50.

2. Parida B, Iniyanb S, Goicc R (2011) A review of solar photovoltaic technologies Renew Sust Energ Rev 15: 1625-1636.

3. Himri Y, Malik AS, Stambouli AB, Himri S, Draoui B (2009) Review and use of the Algerian renewable energy for sustainable development. Renew Sust Energ Rev 13: 1584-91.

4. Mellit A, Kalogirou SA, Hontoria L, Shaari S (2009) Artificial intelligence techniques for sizing photovoltaic systems: a review. Renew Sust Energ Rev 13: 406-19.

5. Hohm DP, Ropp ME (2003) Comparative study of maximum power poin tracking algorithms. Prog Photovoltaics Res Appl 11: 47-62.

6. Salas V, Olias E, Barrado A, Làzaro A (2006) Review of the maximum power point tracking algorithms for stand-alone photovoltaic systems. Sol Energy Mater Sol Cells 90: 1555-1578.

7. Esram T, Chapman PL (2007) Comparison of photovoltaic array maximum power point tracking techniques. IEEE Trans Energy Convers 22: 439-449.

8. Jain S, Agarwal V (2007) Comparison of the performance of maximum power point tracking schemes applied to single-stage grid-connected photovoltaic systems. IET Electr Power Appl 1: 753-762.

9. Femia N, Granozio D, Petrone G, Spagnuolo G, Vitelli M (2007) Predictive \& adaptive mppt perturb and observe method. IEEE Trans. Aerosp Electron Syst 43: 934-950.

10. Yu T, Lin Y (2010) A Study on Maximum Power Point Tracking Algorithms for Photovoltaic Systems. pp: 10.

11. Karabacak K, Cetin N (2014) Artificial neural networks for controlling wind-PV power systems: A review. Renew Sust Energ Rev 29: 804-827.

12. Pukhrem S (2013) A Photovoltaic Panel Model in Matlab / Simulink. pp: 20-23.

13. Ibrahim H, Anani N (2017) Variations of PV module parameters with irradiance and temperature. Energy Procedia 134: 276-285.

14. King DL (1997) Photovoltaic Module and Array Performance Characterization Methods for All System Operating Conditions. AIP Conf Proc 301: 347-368.

15. Mohammad N, Quamruzzaman M, Rubaiyat M, Hossain T (2013) Parasitic Effects on the Performance of DC DC SEPIC in Photovoltaic Maximum Power Point Tracking Applications. Smart Grid Renew. Energy 4: 113-121.

16. Babu BC, Cermak T, Gurjar S, Leonowicz ZM, Piegari L (2015) Analysis of mathematical modeling of PV module with MPPT algorithm. IEEE 15th Int. EEEIC.

17. Bharti RN, Kumar R, Professor M (2014) Modeling and Simulation of Maximum Power Point Tracking for Solar PV System using Perturb and Observe Algorithm. Int J Eng Res Technol 3: 675-681. 
Citation: Khanam J, Foo SY (2018) Modeling of a Photovoltaic Array in MATLAB Simulink and Maximum Power Point Tracking Using Neural Network. J Electr Electron Syst 7: 263. doi: 10.4172/2332-0796.1000263

Page 8 of 8

18. Malek H, Dadras S, Chen Y, Burt R, Cook J (2012) Maximum Power Point Tracking Techniques for Efficient Photovoltaic Microsatellite Power Supply System. AIAA/USU Conf Small Satell. pp: 1-14.

19. Sreekumar AV, Rajendran A (2014) Performance enhancement of PV arrays under partial shading conditions using SEPIC converter. ICCPEIC pp: 218-223.
20. Jayalakshmi NS, Gaonkar DN (2014) Maximum Power Point Tracking for Grid Integrated Variable Speed Wind based Distributed Generation System with Dynamic Load. Vol: 4.

21. Ramani SU, Kumar S, leee K, Arundhati B (2017) Comparitive study of P\&O and incremental conductance method for PV system. ICCPCT. 